\title{
Analisis kualitas struktur dan keberadaan literasi kuantitatif pada lembar kerja peserta didik biologi SMA
}

\section{(An analysis of the quality of structures and the existence of quantitative literacy in biology worksheets for senior high schools students)}

\author{
Ramadhayanti, Soesy Asiah Soesilawaty, Eni Nuraeni \\ Departemen Pendidikan Biologi FPMIPA Universitas Pendidikan Indonesia, Bandung, Indonesia \\ *Corresponding author: ramadhayanti97@gmail.com
}

Received: 18 February 2020 - Accepted: 29 March 2020 - Published: 31 March 2020

\begin{abstract}
The structure quality of student worksheet will determine the actualization of learning objectives required by curriculum. Besides that, as an effort to support the science development to be more quantitative, biology student worksheets should have the quantitative literacy indicators, such as interpretation, representation, calculation, application/ analysis, assumption, and communication. This research is aimed to explain the structure quality and the existence of quantitative literacy in biology student worksheets for senior high school. The research method is quantitative descriptive. The subject of this research is 40 student worksheets in biology book for class 11 published by A, B, and C publisher. The result shows that the student worksheets from A has the best structure quality according to Vee Diagram. The percentage of structure quality of student worksheet in A book is $55,5 \%$, followed by B (53,2\%) and C $(29,9 \%)$. The existence of quantitative literacy that can be identified from the books are interpretation, calculation, application/analysis, and communication. All of the interpretation and calculation indicator found in record/transformation component, while all of the application/analysis indicator found in knowledge claim component. Communication indicator found in two components, record/ transformation (50\%) and knowledge claim $(50 \%)$.
\end{abstract}

Keywords structure quality, quantitative literacy, student worksheet

ABSTRAK Kualitas struktur Lembar Kerja Peserta Didik (LKPD) akan sangat menentukan ketercapaian tujuan pembelajaran yang dituntut oleh kurikulum. Di samping itu, sebagai upaya untuk menunjang perkembangan sains ke arah kuantitatif, suatu LKPD biologi hendaknya mengandung kemampuan literasi kuantitatif, seperti interpretasi, representasi, kalkulasi, aplikasi/analisis, asumsi, dan komunikasi. Penelitian ini bertujuan untuk menjelaskan kualitas struktur dan keberadaan kemampuan literasi kuantitatif pada LKPD biologi jenjang Sekolah Menengah Atas (SMA).Metode yang digunakan dalam penelitian ini adalah deskriptif kuantitatif. Subjek dalam penelitian ini adalah 40 LKPD yang terdapat di dalam buku paket biologi kelas XI yang diterbitkan oleh Penerbit A, B, dan C. Hasil penelitian menunjukkan bahwa kualitas struktur terbaik berdasarkan Diagram Vee dimiliki oleh LKPD pada buku A. Ketercapaian kualitas struktur LKPD pada buku A adalah 55,5\%, diikuti oleh LKPD pada buku B (53,2\%) dan C (29,9\%). Adapun keberadaan kemampuan literasi kuantitatif yang dapat diidentifikasi pada seluruh LKPD dari ketiga buku paket hanya terdiri dari kemampuan interpretasi, kalkulasi, aplikasi/analisis, dan komunikasi. Seluruh kemampuan interpretasi dan kalkulasi ditemukan di komponen catatan/transformasi, sementara seluruh kemampuan aplikasi/analisis ditemukan di komponen klaim pengetahuan. Adapun kemampuan komunikasi ditemukan di dua komponen, yaitu catatan/transformasi (50\%) dan klaim pengetahuan (50\%).

Kata kunci kualitas struktur, literasi kuantitatif, Lembar Kerja Peserta Didik (LKPD)

\section{PENDAHULUAN}

Kegiatan pratikum di laboratorium sains memerlukan suatu media agar peserta didik dapat memperoleh pengetahuan melalui proses pengalaman belajar. Salah satu media pembelajaran yang dapat membantu peserta didik untuk mendapatkan pengalaman belajar tersebut adalah Lembar Kerja Peserta Didik (LKPD) (Rohaeti et al., 2006). Penelitian yang dilakukan oleh Supriatno (2013) menunjukkan bahwa saat ini LKPD atau petunjuk kegiatan laboratorium atau practical guide banyak digunakan untuk membantu kegiatan praktikum peserta didik di laboratorium. Dalam kegiatan praktikum, LKPD seringkali digunakan sebagai panduan untuk mengarahkan peserta didik dalam melaksanakan kegiatan praktikum. Panduan tersebut berupa arahan-arahan yang harus dikerjakan oleh peserta didik ketika melakukan kegiatan praktikum di laboratorium. Dengan demikian, penggunaan LKPD praktikum dapat melatih peserta didik untuk menentukan dan mengembangkan kegiatan laboratorium secara mandiri, serta menjadi pedoman bagi peserta didik untuk mencapai pemahaman terhadap suatu konsep dan prinsip tertentu (Supriatno et al., 2009).

Berbagai bentuk Lembar Kerja Peserta Didik (LKPD) telah diterbitkan dan beredar di lapangan serta digunakan oleh para pendidik di sekolah untuk membimbing peserta 
didik dalam melaksanakan kegiatan laboratorium. LKPD yang beredar di lapangan umumnya bersumber dari buku paket dan merupakan komponen atau bagian penting yang melengkapi buku paket tersebut. Selain itu, ada pula LKPD yang dikembangkan secara mandiri oleh para pendidik sehingga bentuk, struktur, dan pendekatan yang digunakan di dalam LKPD menjadi beragam (Supriatno, 2013). Melalui penggunaan LKPD diharapkan pembelajaran biologi yang dahulunya didominasi oleh metode pembelajaran ceramah oleh pendidik perlahan-lahan beralih menjadi pembelajaran berbasis laboratorium yang mampu memfasilitasi peserta didik untuk membentuk pengetahuan yang sesuai.

Penelitian sebelumnya yang dilakukan oleh Supriatno et al. (2009) menunjukkan bahwa kegiatan laboratorium yang dirancang dalam bentuk Lembar Kerja Peserta Didik (LKPD) yang saat ini beredar di lapangan dan digunakan di sekolah-sekolah memiliki permasalahan. Permasalahan tersebut ditemukan pada langkah kerja yang disusun secara tidak tepat sehingga tidak mampu menunjukkan objek atau peristiwa yang seharusnya diamati oleh peserta didik dalam kegiatan laboratorium. Permasalahan tersebut disebabkan oleh desain langkah kerja atau prosedur praktikum yang digunakan dalam LKPD salah, tidak tepat, tidak terstruktur, menimbulkan beragam penafsiran, atau menggunakan metodologi yang juga tidak benar. Dalam penelitian lain yang dilakukan Supriatno et al. (2009) dijelaskan bahwa permasalahan tersebut juga dapat disebabkan oleh (1) prosedur praktikum yang sulit dikerjakan dan tidak konsisten terhadap pertanyaan fokus, (2) tabel data yang kaku dan dapat memicu timbulnya miskonsepsi, (3) serta lamanya waktu yang diperlukan untuk mengerjakan kegiatan praktikum tersebut.

Berbagai permasalahan yang diungkap oleh beberapa penelitian sebelumnya hendaknya menjadi bahan masukan untuk memperbaiki Lembar Kerja Peserta Didik (LKPD) di masa mendatang. Perbaikan LKPD tersebut diawali dengan pemahaman yang baik terhadap permasalahan yang terdapat di LKPD yang digunakan saat ini. Sebuah kerangka berpikir (heuristik) yang dikembangkan oleh Novak \& Gowin (1984) dapat digunakan sebagai acuan untuk memahami permasalahan yang terdapat dalam rancangan kegiatan laboratorium di LKPD. Heuristik Vee atau Diagram Vee tersebut dapat membantu kita dalam memahami proses pembentukan pengetahuan melalui kegiatan laboratorium yang terdapat dalam suatu LKPD. Diagram Vee memiliki dimensi pengetahuan di sisi kiri dan dimensi pengalaman/kegiatan di sisi kanan. Pada saat peserta didik melakukan kegiatan laboratorium, kedua dimensi tersebut saling berinteraksi satu sama lain melalui pertanyaan fokus yang mengarahkan peserta didik pada objek atau peristiwa yang harus diobservasi untuk membentuk pengetahuan yang sesuai.

Proses pembentukan pengetahuan pada diri peserta didik hendaknya diiringi dengan penguasaan kemampuan literasi kuantitatif karena di abad ke-21 ini biologi sedang diarahkan sebagai sains yang bersifat kuantitatif (Speth et al., 2010). Konsep-konsep dalam keilmuan biologi saat ini tidak hanya didasarkan pada aspek kualitatif, tetapi menjadi lebih kuantitatif dan interdisiplin (Nuraeni et al., 2015). Kemampuan berliterasi kuantitatif yang meliputi kemampuan representasi informasi matematis dalam bentuk angka, simbol, tabel, dan grafik penting digunakan oleh peserta didik agar dapat terlibat dalam isu-isu global yang signifikan (Nuraeni \& Rahmat, 2014).

Menurut National Council on Education and the Disciplines (2001), literasi kuantitatif adalah keterampilan berpikir matematis untuk memahami informasi numerik. Literasi kuantitatif adalah kemampuan untuk menggunakan matematika dalam suatu konteks atau disiplin ilmu tertentu, salah satunya adalah mata pelajaran biologi dimana peserta didik harus menerapkan kemampuan berpikir kuantitatif mengenai permasalahan-permasalahan biologi (Speth et al., 2010). Kegiatan pembelajaran biologi yang dilakukan saat ini mampu memberikan kontribusi terhadap pengembangan kemampuan literasi kuantitatif, khususnya melalui penggunaan Lembar Kerja Peserta Didik (LKPD) praktikum dalam proses pembelajaran biologi. Hal ini dikarenakan kegiatan laboratorium dalam LKPD menyediakan kesempatan bagi peserta didik untuk mengembangkan kemampuan literasi kuantitatif. Namun, sejauh pengetahuan peneliti, penelitian yang mengungkapkan kualitas struktur dan keberadaan literasi kuantitatif pada LKPD masih belum dilaporkan. Oleh karena itu, penelitian ini bertujuan untuk menjelaskan kualitas struktur dan keberadaan literasi kuantitatif pada LKPD biologi jenjang Sekolah Menengah Atas (SMA) yang disusun berdasarkan kurikulum 2013 dan paling banyak digunakan oleh peserta didik di Kota Bandung. Penelitian ini dilakukan dengan menggunakan Diagram Vee untuk menganalisis kualitas struktur LKPD dan indikator literasi kuantitatif yang diadaptasi dari Association of American Colleges and Universities/AAC\&U (2009) untuk menganalisis keberadaan kemampuan literasi kuantitatif dalam LKPD.

\section{METODE}

Metode penelitian yang digunakan dalam penelitian ini adalah metode deskriptif kuantitatif. Subjek dalam penelitian ini adalah LKPD Biologi SMA kelas XI yang bersumber dari buku paket biologi yang paling banyak digunakan oleh peserta didik di Kota Bandung, yaitubuku paket biologi yang diterbitkan oleh Penerbit A, B, dan C. Subjek dalam penelitian ini berjumlah 40 LKPD dan dipilih dengan menggunakan teknik purposive sampling. Pertimbangan yang digunakan dalam penelitian ini adalah LKPD yang berisi langkah-langkah petunjuk praktikum dalam kegiatan laboratorium.

Kualitas struktur LKPD dinilai dengan menggunakan Diagram Vee. Diagram Vee memiliki lima komponen yang terdiri dari pertanyaan fokus (focus question), objek/peristiwa (objects/events), konsep/prinsip/teori (concepts/principles/ theories), catatan/transformasi (records/transformations), dan klaim pengetahuan (knowledge claim). Tiap-tiap komponen LKPD tersebut dinilai kelengkapannya dengan menggunakan rubrik kelengkapan komponen LKPD berdasarkan Diagram Vee. Selain itu, tiap-tiap komponen LKPD juga dianalisis kualitas strukturnya dengan menggunakan rubrik penskorankomponen LKPD berdasarkan Diagram Vee untuk menjelaskan kualitas setiap LKPD. 
Instrumen untuk mengetahui keberadaan literasi kuantitatif pada LKPD adalah rubrik keberadaan kemampuan literasi kuantitatif pada LKPD. Analisis keberadaan kemampuan literasi kuantitatif pada LKPD didasarkan pada indikator-indikator yang terdiri dari interpretasi (interpretation), representasi (representation), kalkulasi (calculation), aplikasi/analisis (application/analysis), asumsi (assumption), dan komunikasi (communication) (AAC\&U, 2009). Keberadaan kemampuan literasi kuantitatif tersebut dianalisis pada seluruh komponen Diagram Vee yang terdapat di dalam LKPD.

Data yang diperoleh dari rubrik kelengkapan komponen LKPD berdasarkan Diagram Vee kemudian diolah ke dalam bentuk persentase (\%) keberadaan tiap komponen Diagram Vee di seluruh LKPD yang dianalisis. Berikutnya, data yang diperoleh dari rubrik penskoran komponen LKPD berdasarkan Diagram Vee juga diolah ke dalam bentuk persentase (\%) skor setiap komponen Diagram Vee untuk seluruh LKPD yang dianalisis. Kualitas struktur LKPD pada setiap buku paket yang dianalisis dihitung berdasarkan persentase (\%) ketercapaian seluruh LKPD terhadap kriteria komponen LKPD menurut Diagram Vee. Selain itu, kualitas struktur LKPD pada setiap buku paket juga dihitung berdasarkan persentase (\%) ketercapaian setiap LKPD terhadap kriteria komponen LKPD menurut Diagram Vee.

Data yang diperoleh dari rubrik keberadaan kemampuan literasi kuantitatif berdasarkan indikatorindikator yang diadaptasi dari AAC\&U (2009) kemudian dianalisis dengan menyertakan deskripsi untuk menjelaskan hasil analisis terhadap pernyataan-pernyataan yang termuat dalam LKPD. Hasil akhir yang diperoleh berupa persentase (\%) keberadaan tiap kemampuan literasi kuantitatif dari seluruh LKPD yang dianalisis.

\section{HASIL DAN PEMBAHASAN}

\section{Keberadaan komponen Diagram Vee di LKPD}

Komponen-komponen Diagram Vee yang dijaring dalam penelitian ini adalah pertanyaan fokus (focus question), objek/peristiwa (object/events), konsep/prinsip/teori (concepts/principles/theories), catatan/transformasi (records/ transformations), dan klaim pengetahuan (knowledge claim). Keberadaan komponen-komponen Diagram Vee tersebut dianalisis di seluruh bagian LKPD dan hasilnya disajikan dalam Gambar 1.

Berdasarkan Gambar 1 diketahui bahwa komponenkomponenDiagram Vee tidak ditemukan di seluruh LKPD. Suatu LKPD hanya dapat memiliki maksimal empat dari lima komponen Diagram Vee. Komponen objek/peristiwa ditemukan di hampir seluruh LKPD dengan persentase $(\%)$ keberadaan tertinggi. Komponen pertanyaan fokus dan catatan/transformasi juga ditemukan di hampir seluruh LKPD, tetapi dengan persentase keberadaan yang sedikit lebih rendah daripada komponen objek/peristiwa. Gambar 1. juga menunjukkan bahwa komponen konsep/prinsip/ teori tidak ditemukan sama sekali di LKPD sebagai bagian dari struktur LKPD tersebut.

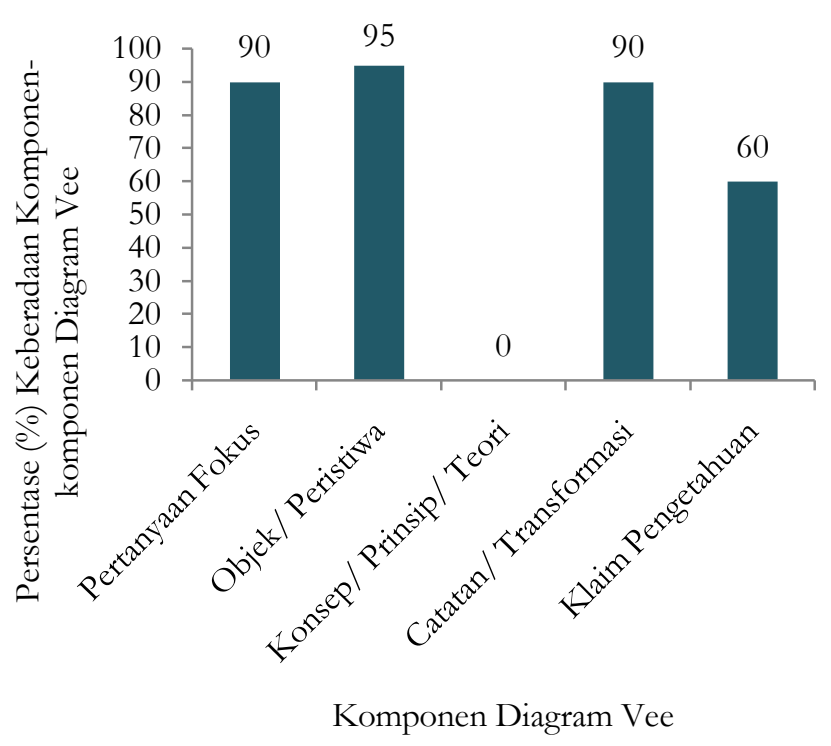

Gambar 1. Keberadaan komponen-komponen Diagram Vee di LKPD

\section{Kualitas pertanyaan fokus di LKPD}

Kualitas pertanyaan fokus (focus question) di seluruh LKPD dapat dilihat pada Gambar 2. Dari seluruh LKPD yang memiliki komponen pertanyaan fokus, tidak seluruhnya memperoleh skor sempurna (skor 3).

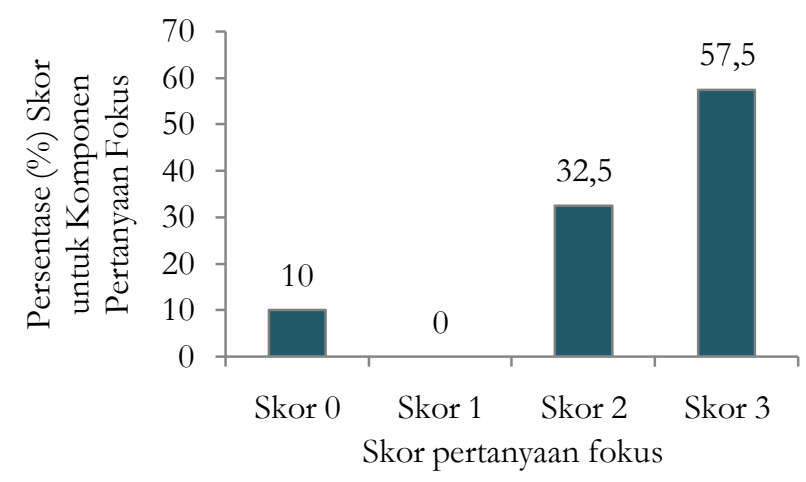

Gambar 2. Perbandingan persentase (\%) skor untuk komponen pertanyaan fokus di LKPD

Kualitas suatu pertanyaan fokus dapat berkaitan dengan letaknya di LKPD sebagaimana yang ditampilkan oleh data pada Gambar 3.

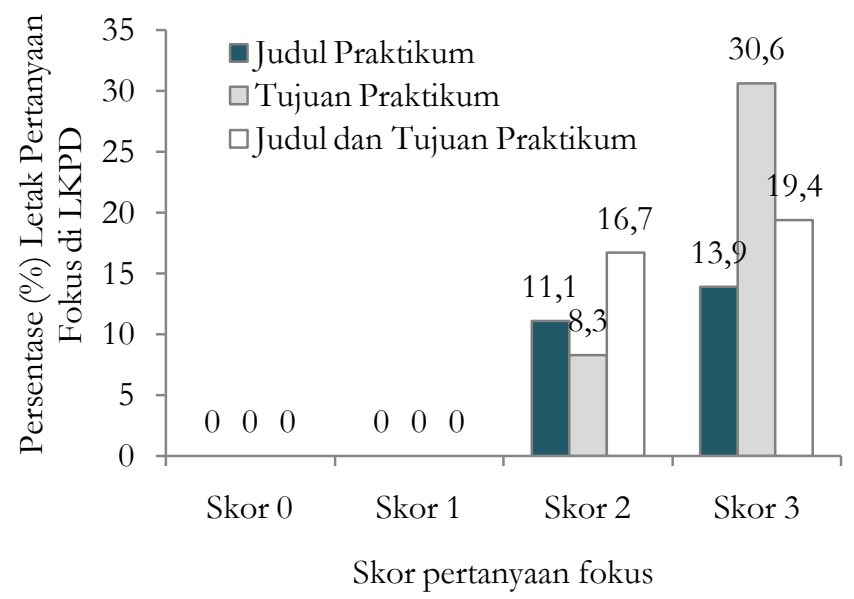

Gambar 3. Letak pertanyaan fokus di LKPD 
Gambar 3 memperlihatkan bahwa LKPD dengan pertanyaan fokus yang ditemukan di bagian tujuan praktikum dan di bagian judul dan tujuan praktikum memiliki perolehan persentase (\%) kualitas yang lebih baik dari pada yang hanya ditemukan di bagian judul praktikum saja. Hal ini dikarenakan pertanyaan fokus yang ditemukan di bagian tujuan praktikum diuraikan dalam satu atau beberapa kalimat sehingga dapat memuat penjelasan yang lebih rinci tentang tujuan atau hasil yang akan dicapai dari suatu kegiatan laboratorium. Pernyataan ini didukung oleh Millar \& Abrahams (2009) yang mengemukakan bahwa pertanyaan focus harus dinyatakan dengan jelas dan akurat agar kegiatan laboratorium dapat berjalan lebih efektif.

\section{Kualitas objek/peristiwa di LKPD}

Kualitas objek/peristiwa (object/events) di seluruh LKPD yang dianalisis dapat dilihat pada Gambar 4.

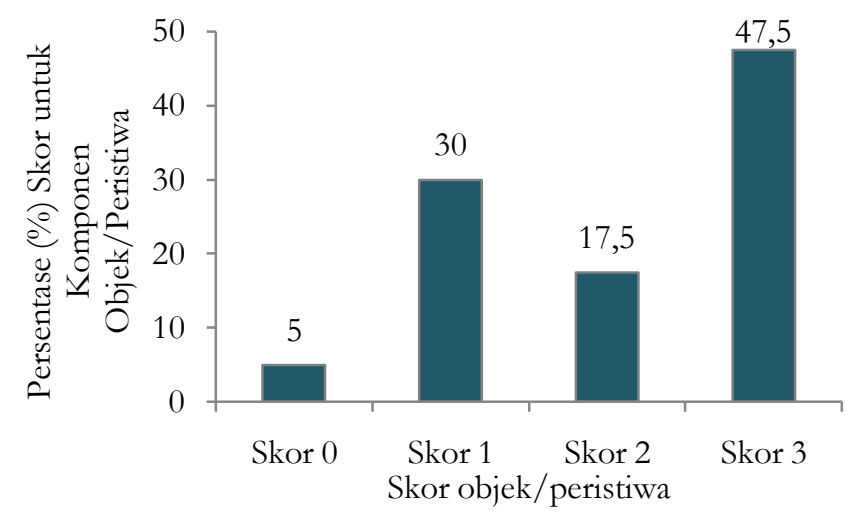

Gambar 4. Perbandingan persentase (\%) skor untuk komponen objek/peristiwa di LKPD

Dari seluruh LKPD yang memiliki komponen objek/peristiwa, hanyakurang dari separuh LKPD yang mendapatkan skor sempurna (skor 3). LKPD dengan komponen objek/peristiwa yang mendapatkan skor sempurna memiliki konsistensi dengan pertanyaan fokus dan mampu mendukung dengan apa yang akan dicatat.

Berbagai permasalahan yang ditemukan pada LKPD yang berkaitan dengan ketidakkonsistenan komponen objek/peristiwa dengan pertanyaan fokus, sejalan dengan penelitian sebelumnya yang dilakukan oleh Supriatno et al. (2009).Ketidakkonsistenan tersebut disebabkan oleh berbagai permasalahan pada LKPD, diantaranya adalah (1) kesalahan prosedur kerja atau prosedur kerja yang tidak lengkap, (2) pemilihan alat dan bahan yang tidak tepat, (3) penggunaan alat dan bahan yang jarang tersedia di laboratorium standar Sekolah Menengah Atas (SMA), serta (4) tidak adanya pertanyaan fokus yang mendukung kemunculan objek/ peristiwa.Berbagai permasalahan tersebut menyebabkan tingkat keberhasilan kemunculan objek/ peristiwa yang hendak diamati oleh peserta didik menjadi sangat rendah.

\section{Kualitas teori/prinsip/konsep di LKPD}

Di seluruh LKPD yang dianalisis, tidak satupun LKPD yang memiliki teori/prinsip/konsep (theory/ principles/concepts) sebagai komponen penyusunnya. Teori/prinsip/konsep yang melandasi atau yang hendak dibuktikan melalui kegiatan laboratorium dapat ditemukan di luar struktur LKPD, tepatnya terintegrasi di bagian uraian atau penjelasan materi yang seluruhnya berisi penjelasan konsep yang berhubungan dengan kegiatan laboratorium di LKPD.Jika ditinjau dari sisi relevansinya, teori/prinsip/konsep yang diuraikan di buku A, B, dan C sudah bersesuaian dengan kegiatan laboratorium yang terdapat di LKPD masing-masing maupun dengan kompetensi dasar yang menjadi tuntutan kurikulum 2013.

\section{Kualitas catatan/transformasi di LKPD}

Kualitas catatan/transformasi di seluruh LKPD dapat dilihat pada Gambar 5. Dari seluruh LKPD yang memiliki komponen catatan/transformasi, hanyakurang dari seperempat LKPD yang meraihskor sempurna (skor 4). LKPD dengan komponen catatan/transformasi yang meraih skor sempurna memiliki kegiatan pencatatan yang disertai dengan transformasi yang konsisten dengan pertanyaan fokus. Gambar 5 menampilkan bahwa persentase tertinggi diraih oleh skor 2. Temuan ini menandakan bahwa LKPD tersebut hanya memiliki salah satu dari komponen catatan atau transformasi. Suatu LKPD dengan komponen catatan berkualitas baik memiliki pencatatan yang relevan dengan objek atau peristiwa yang diamati. Hal ini dikarenakan pencatatan mengandung fakta yang akan dijadikan sebagai informasi yang didapatkan melalui proses transformasi (Supriatno, 2013).

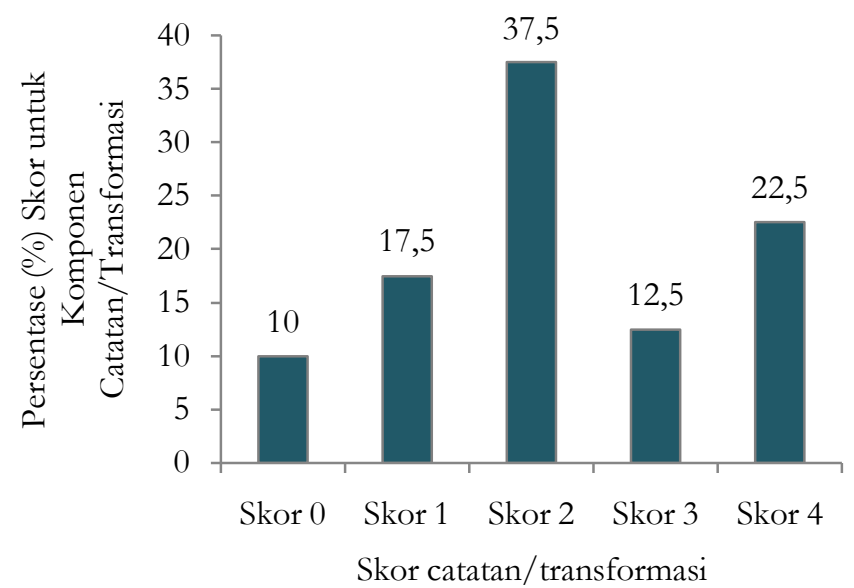

Gambar 5. Perbandingan persentase (\%) skor untuk komponen catatan/transformasi di LKPD

Data yang ditampilkan oleh Gambar 5 didukung oleh temuan tentang keberadaan komponen catatan dan transformasi di LKPD. Hampir setengah jumlah LKPD yang diteliti hanya memiliki komponen catatan saja. Pada LKPD yang hanya memiliki komponen catatan saja tidak ada pertanyaan-pertanyaan pengarah yang akan memandu peserta didik untuk mentransformasikan fakta yang ditemukan dalam kegiatan laboratorium. Keadaan ini menunjukkan bahwa LKPD tersebut hanya meminta peserta didik untuk mengumpulkan data tanpa perlu mengubahnya menjadi suatu informasi melalui proses transformasi. Sebaliknya pada LKPD yang hanya memiliki komponen transformasi saja, peserta didik akan kesulitan untuk menemukan informasi secara tepat karena catatan yang berperan penting untuk mengumpulkan data sebagai bahan transformasi. 
Sebagian besar catatan atau arahan melakukan pencatatan terletak di bagian prosedur kerja, tepatnya di poin terakhir dari prosedur kerja tersebut.Jika ditinjau dari keruntutan bekerja, maka catatan yang terletak di poin terakhir prosedur kerja akan lebih memudahkan peserta didik dan membantu meningkatkan kualitas pencatatannya. Hal ini dikarenakan peserta didik dapat langsung mencatat data yang diperoleh dari hasil pengamatan terhadap objek dan/atau peristiwa yang muncul setelah mereka melakukan serangkaian tahapan dalam prosedur kerja. Jika catatan ditempatkan di antara pertanyaan-pertanyaan pengarah, maka peserta didik akan bekerja bolak-balik -menjawab pertanyaan sembari mencatat dan kemudian lanjut menjawab pertanyaan kembali- untuk melakukan transformasi data. Selain itu, jika objek atau peristiwa yang diteliti tidak dapat bertahan dalam waktu yang lama, maka peserta didik akan kehilangan kesempatan untuk mengumpulkan sebanyak mungkin data yang diperlukan untuk transformasi.

\section{Kualitas klaim pengetahuan di LKPD.}

Kualitas klaim pengetahuan di seluruh LKPD dapat dilihat pada Gambar 6. Dari seluruh LKPD yang memiliki komponen klaim pengetahuan, hanyasebagian kecil saja yang memperoleh skor sempurna (skor 4).

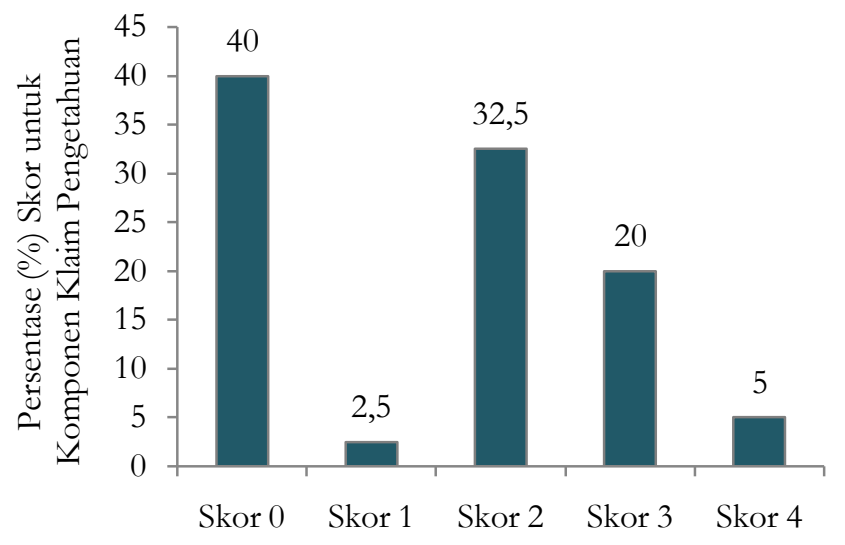

Skor klaim pengetahuan

Gambar 6. Perbandingan persentase (\%) skor untuk komponen klaim pengetahuan di LKPD

LKPD dengan komponen klaim pengetahuan yang memperoleh skor sempurna mengarahkan peserta didik untuk membentuk klaim pengetahuan yang sesuai dengan hasil pencatatan dan transformasi, mengandung konsep yang sesuai dengan pertanyaan fokus, serta mengarah kepada pembentukan pertanyaan fokus baru. Gambar 6 menampilkan bahwa persentase tertinggi justru diraih oleh skor 0 . Temuan ini menandakan bahwa LKPD tersebut tidak meminta peserta didik untuk membuat suatu klaim pengetahuan apapun setelah melakukan kegiatan laboratorium.

Terbentuknya klaim pengetahuan merupakan hasil dari suatu kegiatan laboratorium. Klaim pengetahuan adalah kesimpulan akhir yang harus diperoleh dan dipahami oleh peserta didik. Klaim pengetahuan yang terbentuk juga harus mampu menjawab pertanyaan fokus (Calais, 2009). Tidak adanya arahan atau perintah untuk membentuk klaim pengetahuan menandakan bahwa peserta didik tidak diarahkan untuk mendapatkan prinsip dan konsep untuk menjawab pertanyaan fokus yang telah diberikan atau dirumuskan di awal.

Klaim pengetahuan dapat ditemukan dalam dua bentuk, yaitu secara tersurat melalui arahan untuk membuat kesimpulan mengenai hasil yang diperoleh dari kegiatan praktikum dan secara tersirat melalui pertanyaanpertanyaan pengarah yang relevan dengan hasil yang diperoleh dari kegiatan praktikum.

\section{Perbandingan kualitas struktur LKPD di buku A, B, dan C}

Kualitas struktur LKPD di buku A, B, dan C ditentukan dengan menghitung persentase (\%) ketercapaian seluruh LKPD di masing-masing buku paket terhadap komponen-komponen Diagram Vee. Kualitas struktur untuk setiap buku paket bervariasi (Gambar 7). Secara keseluruhan, capaian persentase kualitas struktur LKPD di buku A dan B relatif berimbang. Sementara, capaian persentase kualitas struktur LKPD di buku C hanya sekitar separuh dari kedua buku lainnya.

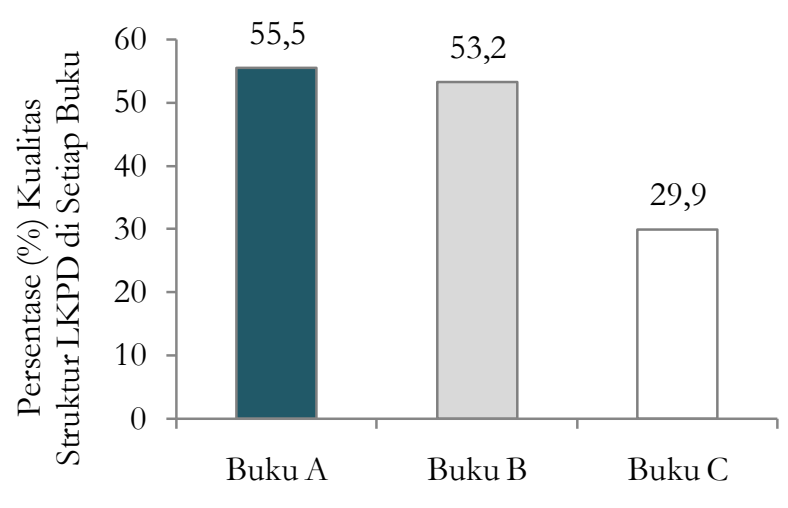

Buku paket yang dianalisis

Gambar 7. Perbandingan kualitas struktur LKPD di buku A, B, dan C

\section{Kualitas struktur LKPD di bukn A}

Berdasarkan Gambar 8, diketahui bahwa kualitas LKPD di buku A bervariasi. Temuan ini menandakan bahwa kualitas setiap LKPD pada buku A berbeda satu sama lain. Kualitas tertinggi berhasil didapatkan oleh dua LKPD, yaitu LKPD 2 dan LKPD 5.

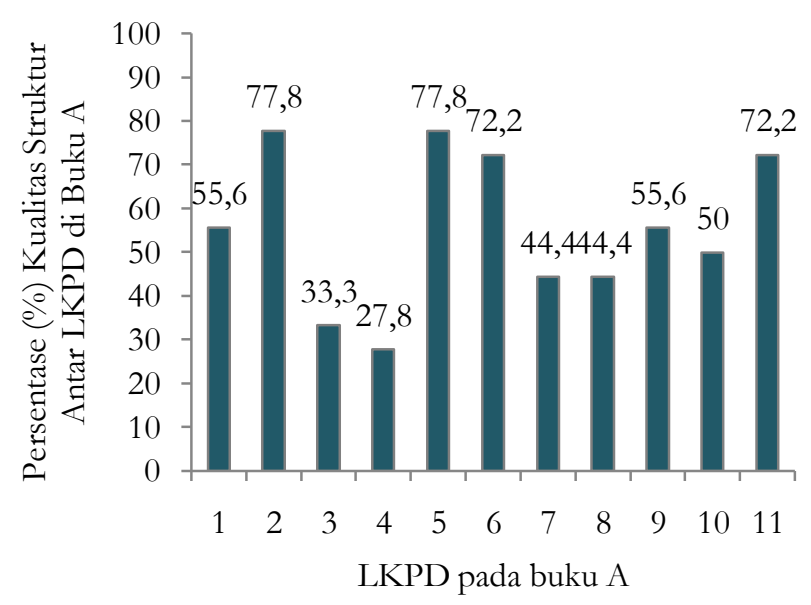

Gambar 8. Perbandingan kualitas strukturantar LKPD di buku A 
LKPD 2 dirancang untuk meraih kompetensi dasar 3.2 dan berisi kegiatan praktikum untuk mengamati fakta gejala difusi dan osmosis. Adapun LKPD 5 dirancang untuk mencapai kompetensi dasar 3.6 dan berisi kegiatan praktikum untuk menguji golongan darah. Kedua LKPD tersebut memiliki kualitas struktur terbaik dari seluruh LKPD di buku A maupun di kedua buku paket lainnya karena mendapatkan skor sempurna untuk empat komponen Diagram Vee, yaitu komponen pertanyaan fokus, objek/peristiwa, catatan/transformasi, dan klaim pengetahuan. Sama seperti seluruh LKPD di ketiga buku paket, kedua LKPD tersebut tidak memiliki komponen konsep/prinsip/teori di dalam struktur LKPD-nya. Komponen konsep/prinsip/teori hanya ditemukan terintegrasi di bagian uraian atau penjelasan materi yang seluruhnya berisi konsep-konsep yang berhubungan dengan kegiatan praktikum dalam LKPD. Di samping memiliki kualitas komponen LKPD yang baik, kegiatan laboratorium yang dirancang di dalam kedua LKPD tersebut juga relevan kompetensi dasarnya.

\section{Kualitas struktur LKPD di buku B}

Kualitas setiap LKPD pada buku B juga berbeda satu sama lain (Gambar 9). Rentang kualitas tertinggi dan terendah yang dicapai oleh LKPD di buku A dan B menunjukkan hasil yang relatif sama sehingga secara keseluruhan kualitas LKPD pada buku B dapat dikatakan sama dengan LKPD pada buku A. Kualitas tertinggi berhasil didapatkan oleh empat LKPD, yaitu LKPD 14, LKPD 15, LKPD 19, dan LKPD 25.

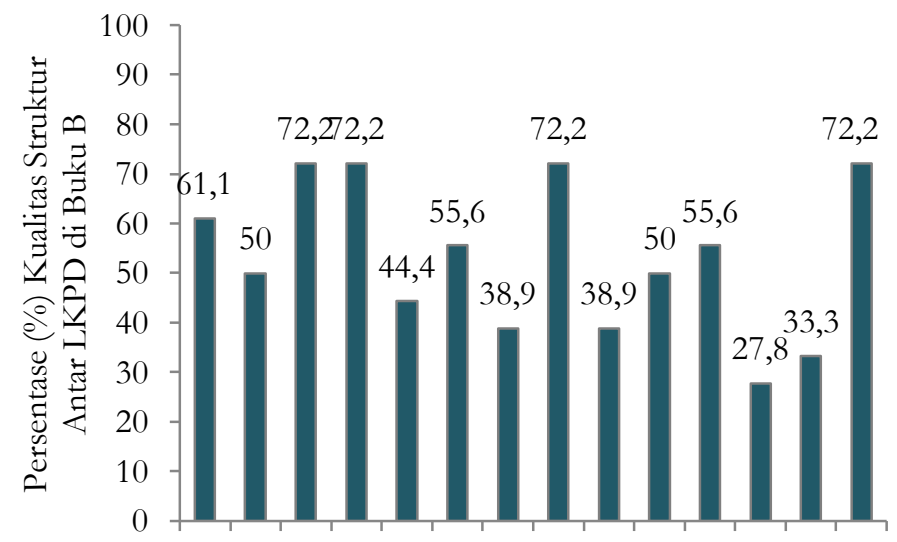

$\begin{array}{llllllllllllll}12 & 13 & 14 & 15 & 16 & 17 & 18 & 19 & 20 & 21 & 22 & 23 & 24 & 25\end{array}$ LKPD pada buku B

Gambar 9. Perbandingan kualitas strukturantar LKPD di buku B

LKPD 14 dan LKPD 15 dirancang untuk meraih kompetensi dasar 3.2. LKPD 14 berisi kegiatan praktikum untuk mengamati proses terjadinya osmosis, sementara LKPD 15 berisi kegiatan praktikum untuk mengamati fasefase mitosis. LKPD 19 disusun untuk memenuhi kompetensi dasar 3.8 dan berisi kegiatan praktikum untuk mengetahui perbedaan frekuensi pernapasan pada aktivitas yang berbeda. Adapun LKPD 25 didesain untuk meraih kompetensi dasar 3.10 dan berisi kegiatan praktikum mengetahui daerah kepekaan rasa pada lidah. Keempat LKPD tersebut memiliki kualitas struktur terbaik dari seluruh LKPD di buku B karena mendapatkan skor

sempurna untuk tiga komponen Diagram Vee, yaitu komponen pertanyaan fokus, objek/peristiwa, dan catatan/transformasi. Komponen klaim pengetahuan belum mampu mencapai kualitas terbaik karena klaim pengetahuan tersebut tidak mengarah kepada pembentukan pertanyaan fokus baru. Di samping memiliki kualitas komponen LKPD yang baik, kegiatan laboratorium yang dirancang di dalam keempat LKPD tersebut juga bersesuaian dengan kompetensi dasarnya.

\section{Kualitas struktur LKPD di buku C}

Kualitas struktur antar LKPD di buku C juga bervariasi seperti pada LKPD di kedua buku lainnya (Gambar 10). Beberapa LKPD di buku C yang mampu mencapai kualitas tertinggi masih jauh dari kualitas baik menurut Diagram Vee. Persentase kualitas tertinggi pada buku $C$ pun adalah yang terkecil daripada kedua buku lainnya. LKPD dengan kualitas tertinggi tersebut adalah LKPD 27, LKPD 28, LKPD 30, dan LKPD 31.
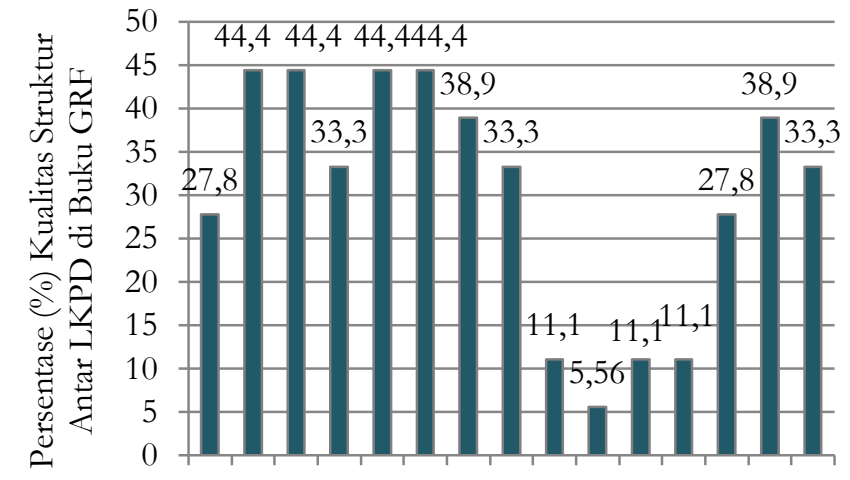

262728293031323334353637383940

LKPD pada buku C

Gambar 10. Perbandingan kualitas struktur antar-LKPD di buku C

LKPD 27 dan LKPD 28 dirancang untuk meraih kompetensi dasar 3.2. LKPD 27 berisi kegiatan praktikum untuk untuk membuktikan fakta difusi zat padat dan zat cair, sementara LKPD 28 berisi kegiatan praktikum untuk mengamati peristiwa osmosis. Adapun LKPD 30 dan LKPD 31 disusun untuk memenuhi kompetensi dasar 3.6. LKPD 30 berisi kegiatan praktikum untuk mengamati proses pembekuan darah, sementara LKPD 31 berisi kegiatan praktikum untuk mengamati struktur jantung. Keempat LKPD tersebut memiliki kualitas struktur terbaik dari seluruh LKPD di buku C, meskipun hanya mampu mendapatkan skor sempurna untuk dua komponen Diagram Vee saja, yaitu komponen pertanyaan fokus dan objek/peristiwa. Komponen catatan/transformasi belum mampu mencapai kualitas terbaik karena keempat LKPD tersebut hanya memiliki komponen catatan saja tanpa disertai dengan transformasi.

Berdasarkan temuan hasil analisis terhadap kualitas strukturantar LKPD di buku C (Gambar 10), dapat diketahui pula bahwa LKPD 35 memiliki kualitas terendah dari seluruh LKPD di buku C dan kedua buku paket lainnya. LKPD 35 dirancang untuk memenuhi kompetensi dasar 3.8 dan berisi kegitan praktikum untuk mengetahui kapasitas vital paru-paru. Dari seluruh komponen Diagram 
Vee, LKPD 35 hanya memiliki komponen objek/peristiwa saja. Komponen objek/peristiwa yang teridentifikasi tersebut juga tidak konsisten (tidak didukung) oleh keberadaan pertanyaan fokus. LKPD 35 tidak memiliki komponen pertanyaan fokus sama sekali, baik secara tersirat dalam tujuan atau komponen lain dalam LKPD, maupun tersurat dalam rumusan masalah. Setelah peserta didik melakukan kegiatan laboratorium, mereka juga tidak diminta untuk membuat catatan dan melakukan transformasi data apapun.

\section{Keberadaan kemampuan literasi kuantitatif di LKPD}

Tidak seluruh kemampuan literasi kuantitatif ada di LKPD (Gambar 11).

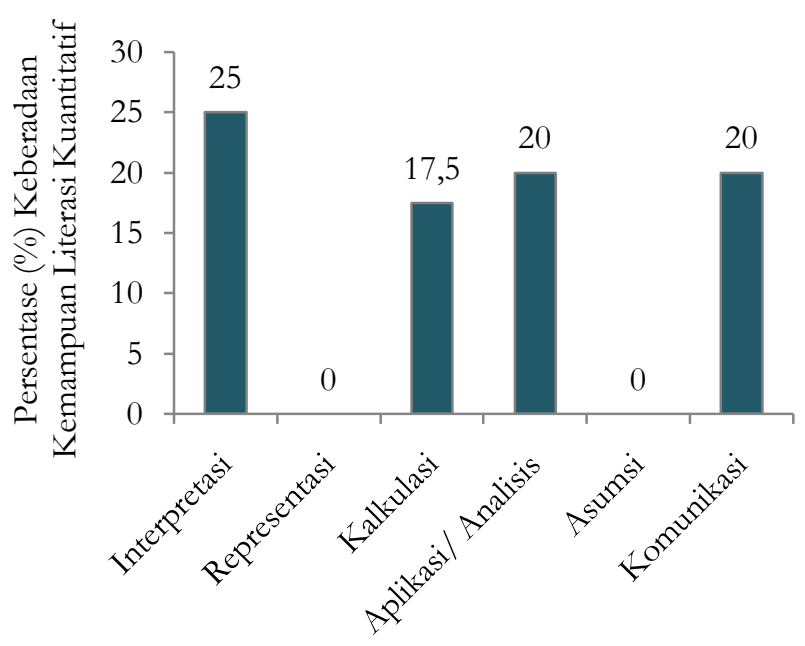

Kemampuan Literasi Kuantitatif

Gambar 11. Keberadaan kemampuan literasi kuantitatif di LKPD

Kemampuan literasi yang teridentifikasi di LKPD hanya kemampuan interpretasi, kalkulasi, aplikasi/analisis, dan komunikasi. Persebaran letak keempat kemampuan tersebut pada komponen Diagram Vee dapat dilihat pada Gambar 12.

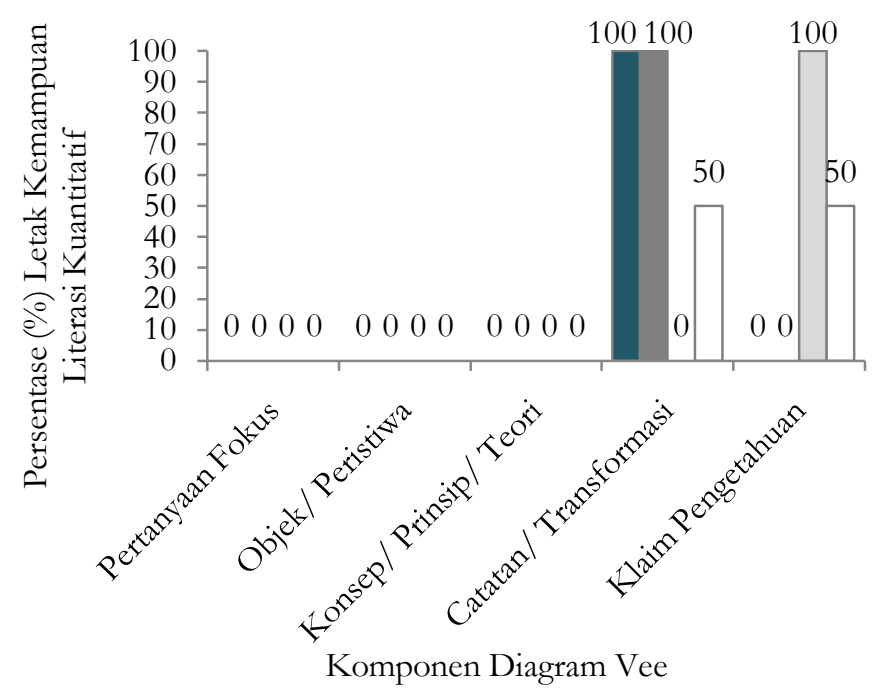

$\square$ Interpretasi $\square$ Kalkulasi $\square$ Aplikasi/Analisis $\square$ Komunikasi

Gambar 12. Letak kemampuan literasi kuantitatif pada komponen Diagram Vee
Gambar 12 menunjukkan bahwa Kemampuan interpretasi dan kalkulasi hanya ditemukan di komponen catatan/transformasi saja. Kemampuan aplikasi/analisis hanya ditemukan di komponen klaim pengetahuan. Adapun kemampuan komunikasi dapat ditemukan di dua komponen, yaitu komponen catatan/transformasi dan klaim pengetahuan dengan persentase (\%) yang sama.

\section{Keberadaan interpretasi}

Interpretasi adalah kemampuan untuk menjelaskan informasi yang disajikan dalam bentuk matematis (misalnya, persamaan, grafik, diagram, tabel, dan kata) (AAC\&U, 2009). Berdasarkan data pada Gambar 11. diketahui bahwa hanya seperempat dari total jumlah LKPD yang dianalisis yang memiliki kemampuan interpretasi di dalamnya.Temuan ini sejalan dengan penelitian yang dilakukan oleh Ardiansyah et al. (2014) yang menyatakan bahwa bahan ajar anatomi tumbuhan yang ada saat ini hanya memenuhi sebagian indikator interpretasi. Dari Gambar 13. diketahui bahwa LKPD pada buku B menduduki persentase tertinggi untuk keberadaan kemampuan interpretasi di dalamnya. Hal ini dikarenakan kemampuan interpretasi pada buku B dapat ditemukan di empat kompetensi dasar yang dianalisis.

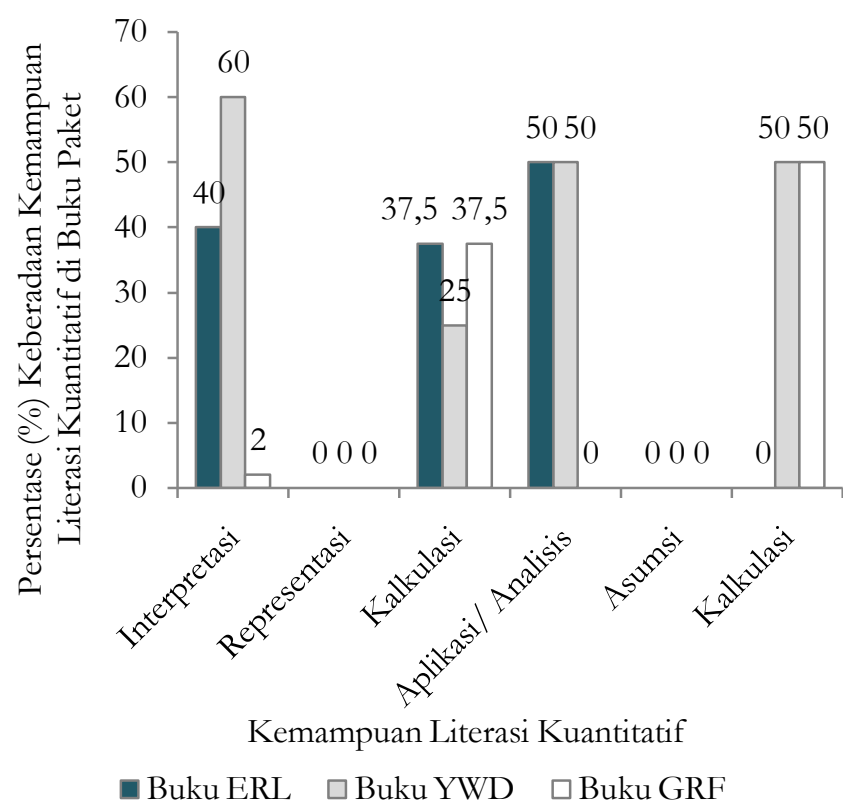

Gambar 13. Keberadaan kemampuan literasi kuantitatif di LKPD pada masing-masing buku paket

Rendahnya persentase keberadaan kemampuan interpretasi dapat dikaitkan dengan rendahnya keberadaan komponen catatan dan transformasi di LKPD. Seluruh kemampuan interpretasi ditemukan di bagian catatan dan transformasi (Gambar 12) karena kegiatan interpretasi memerlukan data yang bersumber dari pencatatan. Selain itu, agar peserta didik dapat melakukan kegiatan interpretasi diperlukan suatu arahan untuk melakukannya melalui proses transformasi.

\section{Keberadaan representasi}

Representasi adalah kemampuan untuk mengubah informasi yang relevan ke dalam berbagai bentuk 
matematis (AAC\&U, 2009). Di seluruh LKPD yang dianalisis, tidak ditemukan satupun LKPD yang memiliki kemampuan representasi (Gambar 11). Temuan ini sejalan dengan pendapat yang dikemukakan oleh Chandrasegaran et al. (2007) bahwa buku teks pelajaran kurang menekankan perbedaan antara tiga level representasi kimia.

\section{Keberadaan kalkulasi}

Kalkulasi adalah kemampuan untuk melakukan perhitungan (AAC\&U, 2009). Kemampuan kalkulasi (calculation) adalah kemampuan literasi kuantitatif yang juga berkaitan erat dengan keberadaan komponen catatan dan transformasi di LKPD. Jika dilihat dari persentase (\%) keberadaannya di LKPD, kemampuan kalkulasi memiliki persentase terendah daripada kemampuan literasi kuantitatif lainnya (Gambar 11). Seluruh kemampuan kalkulasi ditemukan di bagian catatan dan transformasi (Gambar 12) karena pada bagian inilah terjadi proses pengolahan data melalui proses transformasi. Dari Gambar 13. diketahui bahwa LKPD pada buku A dan C menduduki persentase tertinggi untuk keberadaan kemampuan kalkulasi di dalamnya. Meskipun kemampuan kalkulasi di ketiga buku paket tersebut muncul di dua kompetensi dasar, tetapi jumlah LKPD di buku A dan C yang memiliki kemampuan kalkulasi lebih tinggi daripada LKPD di buku B.

\section{Keberadaan aplikasi/analisis}

Aplikasi/analisis adalah kemampuan untuk membuat keputusan dan menggambarkan kesimpulan yang tepat berdasarkan analisis data kuantitatif (AAC\&U, 2009). Kemampuan aplikasi/analisis (application/analysis)adalah kemampuan literasi kuantitatif yang berkaitan erat dengan keberadaan komponen klaim pengetahuan di LKPD. Seluruh kemampuan aplikasi/analisis ditemukan di bagian klaim pengetahuan karena di bagian inilah terdapat arahan untuk membuat kesimpulan (Gambar 12). Temuan tentang keberadaan kemampuan aplikasi/ analisis (Gambar 11) berkaitan dengan temuan tentang keberadaan komponen klaim pengetahuan di LKPD (Gambar 1). Jika kedua data pada Gambar 11 dan Gambar 1. digabungkan, maka dapat disimpulkan bahwa rendahnya persentase keberadaan kemampuan aplikasi/analisis dapat dikaitkan dengan rendahnya keberadaan komponen klaim pengetahuan di LKPD. Dari Gambar 13 diketahui bahwa hanya LKPD pada buku A dan B yang memiliki kemampuan aplikasi/analisis di dalamnya. Kemampuan aplikasi/ analisis pada buku A dan B dapat ditemukan di tiga kompetensi dasar yang dianalisis, meskipun dengan kompetensi dasar yang berbeda.

\section{Keberadaan asumsi}

Asumsi adalah kemampuan untuk membuat dan mengevaluasi asumsi dalam memperkirakan, memodelkan, dan menganalisis data (AAC\&U, 2009). Dari seluruh LKPD yang dianalisis, tidak ditemukan satupun LKPD yang memiliki kemampuan asumsi. Temuan ini sejalan dengan penelitian yang dilakukan oleh Ardiansyah et al. (2014) yang menyatakan bahwa bahan ajar anatomi tumbuhan yang ada saat ini hanya belum memenuhi indikator asumsi.

\section{Keberadaan komunikasi}

Komunikasi adalah kemampuan untuk menyatakan bukti kuantitatif dalam mendukung argumen/pernyataan atau untuk tujuan tertentu (AAC\&U, 2009). Seluruh kemampuan komunikasi ditemukan di bagian klaim pengetahuan (Gambar 12) karena di bagian inilah terdapat arahan untuk membuat kesimpulan. Dari Gambar 13. diketahui bahwa hanya LKPD pada buku B dan C yang memiliki kemampuan komunikasi di dalamnya. Bentuk komunikasi yang diminta pada LKPD berupa komunikasi tertulis dalam bentuk laporan.

\section{SIMPULAN}

Kualitas struktur dan keberadaan kemampuan literasi kuantitatif pada LKPD bervariasi di setiap buku paket. Kualitas struktur terbaik berdasarkan Diagram Vee dimiliki oleh LKPD pada buku A, diikuti oleh LKPD pada buku B dan buku C. Komponen-komponen Diagram Vee yang dapat diidentifikasi adalah pertanyaan fokus, objek/peristiwa, catatan/transformasi, dan klaim pengetahuan. Komponen konsep/prinsip/teori tidak dapat diidentifikasi di dalam struktur LKPD yang dianalisis. Komponen tersebut justru diidentifikasi di luar struktur LKPD, tepatnya terintegrasi di bagian uraian atau penjelasan materi.

Keberadaan kemampuan literasi kuantitatif terbaik berdasarkan indikator literasi kuantitatif dari AAC\&U (2009) dimiliki oleh LKPD pada buku B, diikuti oleh LKPD pada buku A dan buku C. LKPD pada buku B memiliki seluruh kemampuan literasi kuantitatif yang dapat diidentifikasi, yaitu kemampuan interpretasi, kalkulasi, aplikasi/analisis, dan komunikasi. Seluruh kemampuan interpretasi dan kalkulasi terdapat di komponen catatan/transformasi, sementara seluruh kemampuan aplikasi/analisis terdapat di komponen klaim pengetahuan. Adapun kemampuan komunikasi terdapat di dua komponen, yaitu catatan/transformasi dan klaim pengetahuan. Kemampuan interpretasi adalah kemampuan yang paling banyak ditemukan pada LKPD, sementara kemampuan kalkulasi adalah kemampuan yang paling sedikit ditemukan pada LKPD.

\section{REFERENSI}

Ardiansyah, R., Survani, R., Nuraeni, E., Supriatno, B., \& Rahmat, A. (2014). Bahan ajar anatomi tumbuhan untuk menunjang literasi kuantitatif mahasiswa biologi. In Prosiding Mathematics and Sciences Forum, 411-416.

Association of American Colleges and Universities (AAC\&U). (2009). Quantitative Literacy V alue Rubric. [Online]. Retrieved from http://www.aacu.org/ value/rubrics/quantitative-literacy.

Calais, G. J. (2009). The Vee Diagram as a problem solving strategy: Content area reading/writing implications. National Forum Teacher Education Journal, 19(3), 1-8.

Chandrasegaran, L. A., Treagust, D., \& Mocerino, M. (2007). The development of a two-tier multiplechoice diagnostic instrument for evaluating secondary school students ability to describe and 
explain chemical reaction using multiple levels of representation. Chemistry Education Research and Practice, 8(3),293-307.

Millar, R., \& Abrahams, I. (2009). Practical work: Making it more effective. Social Science Research, 91(334), 59-64.

National Council on Education and the Disciplines. (2001). Mathematics and democracy the case for quantitative literacy. United States of America: The Woodrow Wilson National Fellowship Foundation.

Nuraeni, E., \& Rahmat, A. (2014). Persepsi mahapeserta didik calon pendidik biologi tentang literasi kuantitatif. In Prosiding Seminar Nasional dan Workshop Implementasi Kurikulum 2013 Universitas Pakuan Bogor 2014, 238-244.

Novak, J. D., \& Gowin, D. B. (1984). Learning how to learn. US A: Cambridge University.

Nuraeni, E., Redjeki, S., Riandi, \& Rahmat, A. (2015). Perkembangan literasi kuantitatif mahapeserta didik biologi dalam perkuliahan anatomi tumbuhan berbasis dimensi belajar. Jurnal Ilmu Pendidikan, $21(2), 127-135$.
Rohaeti, E., Widjayanti, E., \& Padmaningrum, R. T. (2006). Pengembangan lembar kerja peserta didik (LKS) mata pelajaran sains kimia untuk. SMP kelas VII, VIII, dan IX., Yogyakarta: Jurusan Pendidikan Kimia FMIPA UNY.

Speth, E. B., Momsen, J. L., Moyerbrailean, G. A., EbertMay, D., Long, T. M., Wyse, S., \& Linton, D. (2010). 1, 2, 3, 4: Infusing Quantitative Literacy into Introductory Biology. CBE-Life Sciences Education, 9(3), 323-332.

Supriatno, B. (2013). Pengembangan program perkuliaban pengembangan praktikum biologi sekolah berbasis ANCORB untuk mengembangkan kemampuan merancang dan mengembangkan desain kegiatan laboratorium. (Disertasi). Bandung: Sekolah Pasca Sarjana, Universitas Pendidikan Indonesia.

Supriatno, B., Rustaman, N., Redjeki, S., \& Sudargo, F. (2009). Uji langkah kerja laboratorium biologi sekolah. In Prosiding Seminar Nasional Jurusan Pendidikan Biologi. Bandung: UPI Press.

Conflict of Interest Statement: The author(s) declare that the research was conducted in the absence of any commercial or financial relationships that could be construed as a potential conflict of interest.

How to Cite: Ramadhayanti, Soesilawaty, S. A., \& Nuraeni, E. (2020). Analisis kualitas struktur dan keberadaan literasi kuantitatif pada lembar kerja peserta didik biologi SMA. Assimilation: Indonesian Journal of Biology Education, 3(1), 25-33. 